\title{
A Prospective Comparative Study of Reamed vs. Unreamed Nailing in Fractures Shaft of Tibia
}

\author{
Dinesh Choudary, MS Orth, B Kanthimathi, DNB Orth \\ Department of Orthopaedics, Annamalai University, Chidambaram, India
}

\begin{abstract}
Background: Although the tibia is one of the most commonly fractured long bones in the body, there are two accepted management techniques: reamed and unreamed nailing. There is not a general consensus as to which technique is more advantageous to the patient. Patients and methods: This was a single centre prospective randomized trial of 38 adults with a tibial shaft fracture who were treated with either reamed or unreamed nailing. Results: Overall fracture healing time was 23 weeks in the reamed group and 25 weeks in the unreamed group. Differences in rate of clinical union, clinical outcome, time for weight bearing and complications in both the groups were not statistically significant. Conclusion: There are no clear indications or contraindications to favour either reamed or unreamed nailing over the other. Technique, fracture union, functional outcome and complications are similar in both groups. Considering the ease of technique application and the decreased operative time, unreamed interlocking nailing has an edge over reamed interlocking nailing.
\end{abstract}

Key Words:

Reamed, unreamed, interlocking nailing, fracture shaft of tibia

\section{INTRODUCTION}

The tibia is one of the most commonly fractured long bones in the body and a major cause of morbidity ${ }^{1,2}$. These fractures pose a serious problem because of their subcutaneous location and precarious blood supply and resultant problems in union. Trauma surgeons have not yet reached a consensus on a single treatment protocol for all patients with tibial shaft fractures. Fractures of the tibia cannot be treated successfully in all cases with only one approach or a single simple set of rules ${ }^{2-4}$. In this study, two modalities of fixation of shaft of tibia fractures were chosen and compared: 1) reamed interlocking intramedullary nailing; and 2) unreamed interlocking intramedullary nailing

\section{PATIENTS AND METHODS}

A prospective randomized comparative study was conducted to evaluate technique, outcome and time to clinical and radiological union following reamed vs. unreamed interlocking nailing. Advantages, disadvantages, follow up and complications if any and overall functional outcome were evaluated. Clinical and radiological follow-up took place in the immediate postoperative period and subsequently at periodic intervals enabling comparison of the two techniques.

Thirty-eight patients with tibial shaft fractures treated in the Department of Orthopaedics, Rajah Muthiah Medical College and Hospital, Annamalai University, Chidambaram, admitted from May 2009 to May 2011 comprised the study group. Skeletally mature patients were chosen for the study and comparisons were made after treating the fractures with either reamed or unreamed interlocking nails. Skeletally immature patients, fractures extending to an articular surface, fractures with neurovascular injuries and pathological fractures were excluded from the study.

In cases of open fractures, thorough wound debridement was performed in the emergency theatre on the day of admission. Antibiotic prophylaxis and tetanus prophylaxis were administered and wound dressing was performed; internal fixation was undertaken at an appropriate time. All fractures were classified according to AO classification for diaphyseal fractures of tibia. The degree of comminution was assessed according to Winquist and Hansen's classification ${ }^{5}$. In closed fractures, the Tscherne and Gotzen classification ${ }^{6}$ for soft tissue was used.

All the patients underwent fracture fixation under spinal/epidural anaesthesia. Patients were placed on the fracture table with the injured leg bent at 90 degrees at the knee with the help of a padded attachment ${ }^{7,28}$ and tourniquet ${ }^{8}$ for all cases. An anterior midline patellar ligament splitting approach was used for both techniques. Nail length was measured preoperatively and the most commonly used nail diameter was 9 and $10 \mathrm{~mm}$.

For the reamed group, reaming was carried out for the entire extent of the medullary canal in a sequence of $0.5-\mathrm{mm}$ increments using flexible reamers. The canal was reamed to $1 \mathrm{~mm}$ more than the diameter of the nail. The appropriate length of the nails that were to be inserted after reaming was determined with use of the guide-rod subtraction method. In 
Table I: Anatomical parameters of Atlas

\begin{tabular}{|c|c|c|c|c|}
\hline & & Total & Reamed & Unreamed \\
\hline \multirow[t]{3}{*}{ 1) } & Gender & Total & Reamed & Unreamed \\
\hline & Male & 30 & 16 & 14 \\
\hline & Female & 08 & 4 & 4 \\
\hline \multirow[t]{3}{*}{ 2) } & Affected limb & Total & Reamed & Unreamed \\
\hline & Right & 23 & 14 & 9 \\
\hline & Left & 15 & 6 & 9 \\
\hline \multirow[t]{4}{*}{ 3) } & Fracture Site & Total & Reamed & Unreamed \\
\hline & Proximal & 11 & 6 & 5 \\
\hline & Midle & 13 & 7 & 6 \\
\hline & Distal & 14 & 7 & 7 \\
\hline \multirow[t]{4}{*}{ 4) } & $\begin{array}{l}\text { Fracture Type } \\
\text { a) AO Classification }\end{array}$ & Total & Reamed & Unreamed \\
\hline & A & 16 & 10 & 6 \\
\hline & B & 11 & 6 & 5 \\
\hline & $\mathrm{C}$ & 11 & 4 & 7 \\
\hline \multirow[t]{5}{*}{ b) } & Winquist and Hansen & & & \\
\hline & 1 & 22 & 12 & 10 \\
\hline & II & 10 & 6 & 4 \\
\hline & III & 5 & 2 & 3 \\
\hline & IV & 1 & 0 & 1 \\
\hline \multirow[t]{7}{*}{ 5) } & Screw breakage & 1 & 1 & 0 \\
\hline & Nonunion & 1 & 1 & 0 \\
\hline & Knee pain & 2 & 1 & 1 \\
\hline & Knee stiffness & 2 & 1 & 1 \\
\hline & Ankle joint stiffness & 3 & 1 & 2 \\
\hline & Superficial infection & 1 & 1 & 0 \\
\hline & External rotation deformity & 1 & 0 & 1 \\
\hline
\end{tabular}

the unreamed group, reaming was limited only to the proximal 6 to $8 \mathrm{~cm}$ of the metaphysis to accommodate the proximal flare of the nail. The diameter of the nail was determined by the measurement of the narrowest diaphyseal diameter of anteroposterior and lateral radiograph.

Insertion of the nail was controlled under image intensification. Whether to provide static or dynamic locking and the number of interlocking screws were determined according to fracture geometry. Proximal interlocking was carried out with the aid of nail mounted targeting devices, whereas distal interlocking was carried out with a freehand technique under an image intensifier.

\section{RESULTS}

The average operating time for reamed nailing was 70 minutes and the average operating time for unreamed nailing was 55 minutes. The patients were evaluated immediately post op, six weeks, six months and one year after surgery. There were 30 male and 8 female study participants with an average age of 25 years (range, 21-30y). Twenty-three patients had right sided injuries while 15 had left sided injuries, and high velocity motor traffic accidents were the most common cause of injury. Alternating cases were treated with either reamed or unreamed interlocking nailing of the tibia to simulate a randomized controlled trial.
Twenty cases were treated with reamed nailing while 18 were treated with unreamed nailing. There were 16 AO type A fractures, 11 type $\mathrm{B}$ and 11 type $\mathrm{C}$ fractures. Based on the Winquist and Hansen classification, 22 cases were type I, 10 were type II, 5 were type III and one was type IV. Eleven fractures were located in the upper third of the tibia, 13 were in the middle third and remaining 14 were in lower third. There were 6 open fractures in the reamed group and 3 open fractures in the unreamed group (Table I).

Outcomes including complications encountered, rate of clinical union and rate of radiological union were documented and compared between the reamed and unreamed groups using the Johner and Wruh's criteria ${ }^{9}$.

There were no significant differences in patient age, gender, mode of injury or overall distribution of fracture types between the reamed and unreamed groups. The average time to clinical union in the reamed group was 20.5 weeks. One patient did not show union by 26 weeks. Average time to clinical union in the unreamed group was 22.5 weeks. The average radiological union in the reamed group was seen at 23 weeks and one patient did not show radiological union beyond 28 weeks. In the unreamed group the average radiological union time was 25 weeks.

In the reamed group, out of 20 cases, six developed complications. There was one case of nonunion ${ }^{11}$, one case each of superficial infection ${ }^{10,11,29}$, screw breakage ${ }^{12}$, knee stiffness, ankle stiffness and knee pain ${ }^{13}$. In the unreamed 


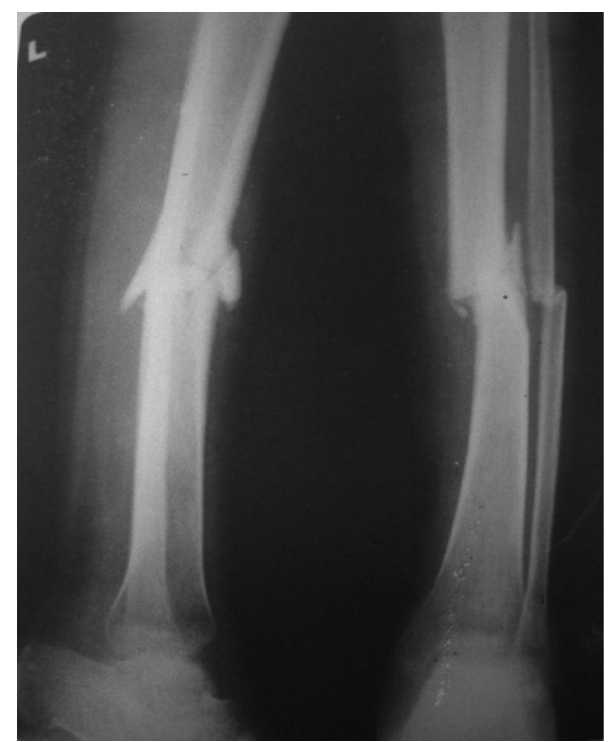

Fig. 1: Preoperative radiograph of patient before reamed nailing.

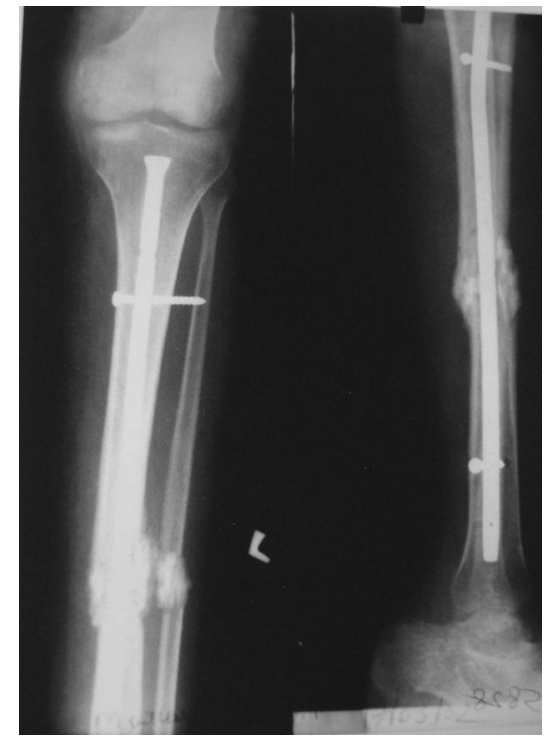

Fig. 2: Postoperative radiograph reamed nailing procedure.

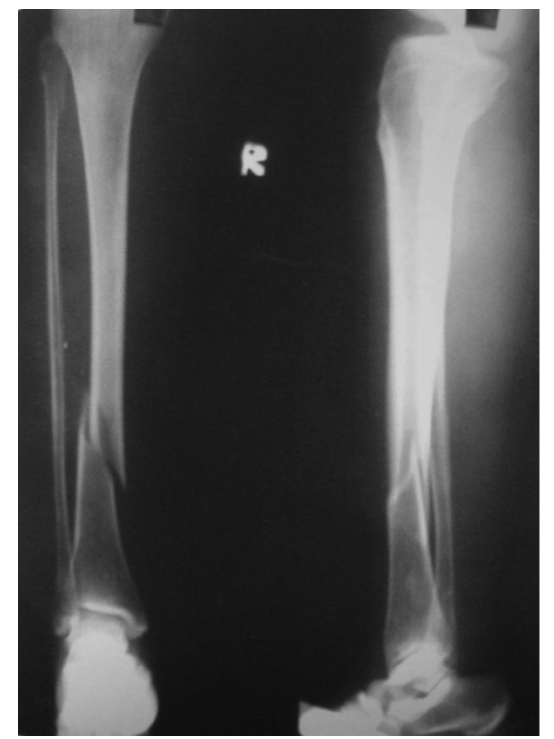

Fig. 3: Preoperative unreamed procedure.

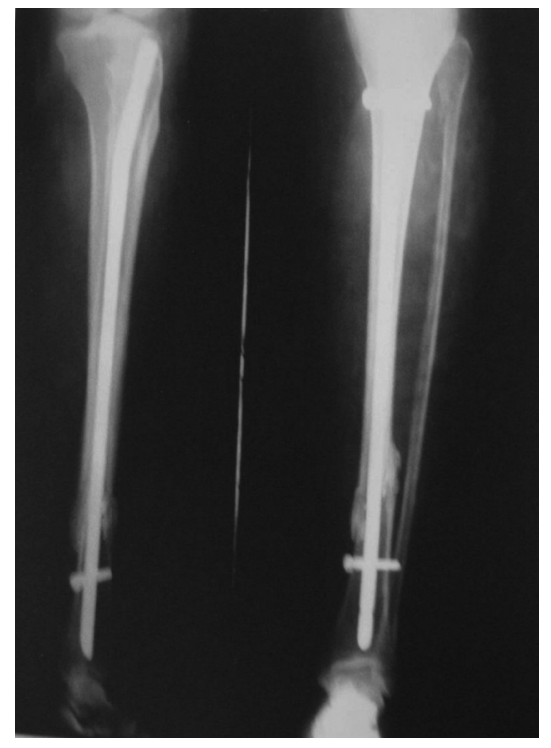

Fig. 4: Postoperative radiograph, unreamed procedure.

group, out of 18 cases, 5 cases developed complications. There was one case of external rotation deformity, one case of knee stiffness, 2 cases of ankle joint stiffness and one case of knee pain ${ }^{13}$.

Functional results were graded based on Johner and Wruh's criteria $^{9}$. In the reamed group, 16 cases showed excellent results $(80 \%)$ while 2 cases showed fair results $(10 \%)$ and 2 cases poor results $(10 \%)$. In the unreamed group, 13 cases showed excellent results $(72.22 \%), 2$ cases had good results $(11.11 \%), 2$ cases fair results $(11.11 \%)$ and one case had poor results $(5.55 \%)$.

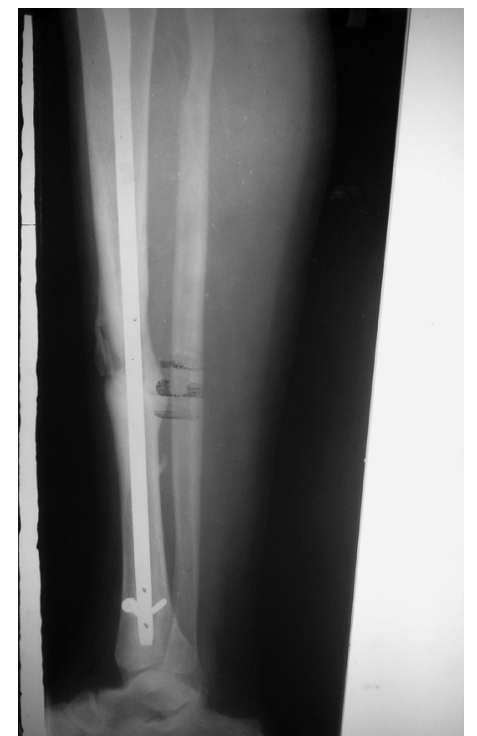

Fig. 5: Radiograph showing screw breakage, a complication of reamed nailing.

\section{DISCUSSION}

The tibia is one of the most commonly fractured bones in the body and intramedullary fixation of tibial shaft fractures has gained popularity in recent years with the development of interlocking nails. This technique is currently used to stabilize unstable diaphyseal tibial fractures. However, differing surgeons advocate two different methods of nail insertion, i.e., with and without reaming of the medullary canal. Each method has specific advantages and disadvantages and controversy still continues regarding which method is warranted for specific clinical situations. 
While reaming can cause devascularisation of the cortex and thermal necrosis of the inner $50-70 \%$ of the cortex ${ }^{14,15}$ thus delaying healing, it can also help to fix the fracture with a larger size nail thus achieving better stability ${ }^{16,25,26,30}$. The effects of reaming on fat embolism should also be considered.

In unreamed nailing, there is less risk of fat embolism and several studies suggest better preservation and more-rapid recovery of the intraosseous blood supply after insertion of a small-diameter nail without reaming ${ }^{17-22}$. In contrast, studies by Blachut et al. ${ }^{23}$ and Court Brown et al. ${ }^{24}$ seem to indicate that nonunion occurs more frequently with unreamed nailing 17,25,26. Some studies indicate increased incidence of screw breakage with unreamed nailing ${ }^{23,27}$.

In the present study, there were sixteen AO type A fractures. Out of these 16, twelve fractures showed excellent results, three fractures showed fair results and one showed poor results. Eleven cases had AO type B fracture and of these, seven cases had excellent results, one case had good results, one case had fair result and two cases had poor results. Eleven cases had AO type $\mathrm{C}$ fractures and of these, ten cases had excellent results while one case had good results.

Among the reamed group, ten cases had AO type A fracture out of which seven cases showed excellent results, two cases showed fair results and one case showed poor results. Six cases in the reamed group had AO type B fracture with five cases showing excellent results and one case showing poor results. Only four cases had AO type $\mathrm{C}$ fracture with all four showing excellent results.

In the unreamed group, six cases had AO type A fracture with one case showing fair results and the remaining five cases with excellent results. Five cases had AO type B fractures with one case each showing good, fair and poor results and the remaining two cases showing excellent results. Seven cases had AO type $\mathrm{C}$ fractures with one case showing good results and remaining six cases showing excellent results.

Based on the Winquist and Hansen classification, there were a total of twenty two Type I fractures, out of which sixteen cases had excellent results, one case had good results, three cases had fair results and two cases had poor results. Ten Winquist and Hansen type II fractures were present out of which one case had poor results and nine cases had excellent results. Winquist and Hansen type III fractures were seen on five cases out of which one case had good results and one case had fair results with the remaining three cases having excellent results. There was only one Winquist and Hansen type IV fracture and it had excellent results.
Among the reamed group, there were twelve Winquist and Hansen type I fractures, out of which two cases had fair results and one case had poor results leaving nine cases with excellent results. There were six Winquist and Hansen type II fractures, out of which one case had poor results and five had excellent results. There were two cases of Winquist and Hansen type III fracture both of which had excellent results. There were no cases of Winquist and Hansen type IV fractures in the reamed group.

In the unreamed group, there were ten Winquist and Hansen type I fractures out of which seven cases had excellent results, one had good results, one case had fair results and one case had poor results. There were four Winquist and Hansen type II fractures and all four had excellent results. Three Winquist and Hansen type III fractures were present out of which one case had fair results, one case good results and one case had excellent results. There was one case of Winquist and Hansen type IV fracture which had excellent results.

The overall outcomes in this study showed $80 \%$ good to excellent results with reamed interlocking nailing, whereas we found $72.22 \%$ good to excellent results with unreamed interlocking nailing. The type of fracture did not significantly alter the outcome. The pattern of fracture was similar in both groups. The age distribution was identical. A majority of $t$ patients, 30 of 38 , were males. As the number of female patients was only 8 , distributed as 4 in each group, we conclude that gender difference did not play a role in final outcomes.

Although, theoretically reaming increases the risk of fat embolism, no such reports are evident in clinical setting. Though some studies indicate that nonunion occurs more frequently in unreamed nailing, that did not seem to be the case in this study.

\section{CONCLUSION}

Intramedullary nailing is the proven choice of treatment for adult tibial shaft fractures, despite the fact that controversy exists regarding the choice of reamed or unreamed intramedullary nailing. There are no clear indications or contraindications for choosing either option.

The rate of clinical and radiological fracture union, functional outcome and complications were similar in both the study groups. Considering the ease of performing the technique and the decreased operative time, unreamed interlocking nailing may have an edge over reamed interlocking nailing. 


\section{REFERENCES}

1. Sarmiento A, Shajpe FE, Factor influencing the outcome of closed tibial fractures treated with functional cost bracing, Clin Orthop Relat Res. 1995; 315: 8-12.

2. Nicoll EA. Fractures of the tibial shaft: a survey of 705 cases. J Bone Joint Br. 1964; 46B: 373-87.

3. Charnley. J treatment of common fractures.Edinburgh: Cambridge University Press; 1961. Pp. 209-49.

4. Littenberg B, Weinstein LP, McCarren M, Mead T, Swiontkowski MF, Rudicel SA, Heck D. Closed fractures of the tibial shaft. A meta-analysis of three methods of treatment. J Bone Joint Am. 1998; 80 (2): 174-83.

5. Veith RG, Winquist RA, Hansen ST Jr. Ipsilateral fractures of the femur and tibia- A Report of 51 consecutive cases. J Bone Joint Surg Am. 1984; 66(7): 991-100

6. Western HJ, Tscherne H. Pathophysiology and classification of soft tissue injuries associated with fractures. In: Tscherne H, Gotzen L, Fractures with soft tissue injuries. Berlin: Springer - Verleg 1984:1-9.

7. Campbell's Operative Orthopaedics 10 edition.pp. 2067-94

8. Salam AA, Eyres KS, Cleary J, El-Sayeed HH. The use of Tourniquet when plating tibial fractures. J Bone Joint Surg Br. 1991; 73(1): 86-7.

9. Johner R, Wruhs O. Classification of tibial shaft fractures and correlation with result after rigid internal fixation. Clin Orthop Relat Res. 1983; (178): 7-25.

10. Bone LB, Johnson KD. Treatment of tibial fractures by reaming and intramedullary nailing. J Bone Joint Surg Am. 1986; 68(6): $877-87$

11. Malik MH, Harwood P, Diggle P, Khan SA. Factors affecting rates of infection and nonunioun in intramedullary nailing. $J$ Bone Joint Surg Br. 2004; 86(4): 556-60

12. Greitbauer M, Heinz T, Gaebler C, Stoik W, Vécsei V. Unreamed nailing of tibial fractures with the solid tibial nail. Clin Orthop Relat Res. 1998; (350): 105-14.

13. Hernigou P, Cohen D. Proximal entry for intramedullary nailing at the tibia - The risk of unrecognized articular damage. $J$ Bone Joint Surg Br. 2000; 82(1): 33-41.

14. Leunig M, Hertel R. Thermal necrosis after tibial reaming for intramedullary nail fixation: A report of three cases. $J$ Bone Joint Surg Br. 1996; 78(4): 584-7.

15. Watson JT. Treatment of unstable fractures of the shaft of the tibia. J Bone Joint Surg Am. 1994; 76(10): 1575-84.

16. Koval KJ, Clapper MF, Brumback RJ, Ellison PS Jr, Poka A, Bathon GH, Burgess AR. Complication of reamed intramedullary nailing of tibia. J Orthop Trauma. 1991; 5(2): 184-9

17. Anglen JO, Blue JM.A comparison of reamed and unreamed nailing of the tibia. J Trauma. 1995; 39(2): 351-5.

18. Harvey FJ, Hodgkinson AH, Harvey PM. Intramedullary nailing in the treatment of open fractures of the tibia and fibula. $J$ Bone Joint Surg Am. 1975; 57(7): 909-15.

19. Joshi D, Ahmed A, Krishna L, Lai Y. Unreamed interlocking nailing in open fractures of tibia. J Orthop Surg (Hong Kong). 2004; 12(2): 216-21.

20. Kutty S, Farooq M, Murphy D, Kelliher C, Condon F, McElwain JP. Tibial shaft fractures treated with the AO unreamed tibial nail. Ir J Med Sci. 2003; 172(3): 141-2

21. Whittle AP, Russell TA, Taylor JC, Lavelle DG. Treatment of open fractures of the tibial shaft with the use of interlocking nailing without reaming. J Bone Joint Surg Am. 1992; 74(8): 1162-71.

22. Gaebler C, Berger U, Schandelmaier P, Greitbauer M, Schauwecker HH, Applegate B et al. Rates and odds ratios for complications in closed and open tibial fractures treated with unreamed, small diameter tibial nails: a multicenter analysis of 467 cases. J Orthop Trauma. 2001; 15(6): 415-23.

23. Blachut PA, O'Brien PJ, Meek RN, Broekhuyse HM. Interlocking Intramedullary nailing with and without reaming for the treatment of closed fractures of the tibial shaft. A prospective randomized study. J Bone Joint Surg Am. 1997; 79(5): 640-6.

24. Court-Brown CM, Keating JF, Christie J, McQueen MM. Exchange intramedullary nailing. Its use in aseptic tibial nonunion. $J$ Bone Joint Surg Br. 1995; 77(3): 407-11. 
25. Finkemeier CG, Schmidt AH, Kyle RF, Templeman DC, Varecka TF. A prospective, randomized study of intramedullary nails inserted with and without reaming for the treatment of open and closed fractures of the tibial shaft. J Orthop Trauma. 2000; 14(3): 187-93.

26. Larsen LB, Madsen JE, Høiness PR, Øvre S. Should insertion of intramedullary nails for tibial fractures be with or without reaming? A prospective randomized study with 3.8 year's follow up. J Orthop Trauma. 2004; 18(3): 144-9.

27. Keating JF, O'Brien PJ, Blachut PA, Meek RN, Broekhuyse HM. Locking intramedullary nailing with and without reaming for open fractures of the tibial shaft. A prospective randomized study. J Bone Joint Surg Am. 1997; 79(3): 334-41.

28. Russell TA: Fractures of the Tibia and Fibula; in Rockwood CA, Green DP, Bucholz RW: Rockwood and Green's Fractures in Adults, 4rd edition, JB Lippincott, NY, NY, 1996; 2127-200

29. Gustilo RB, Anderson JT. Prevention of infection in the treatment of one thousand and twenty five open fractures of long bones: retrospective and prospective analysis. J Bone Joint Surg Am. 1976; 58(4): 453-8.

30. Bhandari M, Guyatt G, Tornetta P 3rd, Schemitsch EH, Swiontkowski M, Sanders D, Walter SD. Randomized trial of reamed and unreamed nailing of tibial shaft fractures. J Bone Joint Surg Am. 2008; 90(12): 2567-78. 